\title{
Bacterial Communities Along Environmental Gradients in Tropical Soda Lakes
}

\section{Thierry A. Pellegrinetti}

University of São Paulo

Simone R. Cotta

University of São Paulo

\section{Hugo Sarmento}

Federal University of São Carlos (UFSCar)

Juliana S. Costa

University of São Paulo

Endrews Delbaje

University of São Paulo

Celia R Montes

University of São Paulo

Plinio B Camargo

University of São Paulo

Laurent Barbiero

Paul Sabatier University

Ary T Rezende-Filho

Federal University of Mato Grosso do Sul

Marli Fatima Fiore ( $\nabla$ fiore@cena.usp.br)

Universidade de Sao Paulo https://orcid.org/0000-0003-2555-7967

\section{Research Article}

Keywords: Microbial ecology, extreme environment, saline-alkaline lakes, cyanobacterial blooms

Posted Date: January 3rd, 2022

DOI: https://doi.org/10.21203/rs.3.rs-1196209/v1

License: (9) This work is licensed under a Creative Commons Attribution 4.0 International License.

Read Full License 
Telephone: +551934294611 Filho $^{\mathrm{d}}$, Marli F. Fiore $\mathrm{a}^{*}$

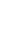
Piracicaba, São Paulo, Brazil São Carlos, São Paulo, Brazil F31400, Toulouse, France

\section{lakes}

Thierry A. Pellegrinetti ${ }^{\mathrm{a}}$, Simone R. Cotta ${ }^{\mathrm{a}}$, Hugo Sarmento ${ }^{\mathrm{b}}$, Juliana S. Costa ${ }^{\mathrm{a}}$, Endrews

Delbaje $^{\mathrm{a}}$, Celia R. Montes ${ }^{\mathrm{a}}$, Plinio B. Camargo ${ }^{\mathrm{a}}$, Laurent Barbiero ${ }^{\mathrm{c}}$, Ary T. Rezende-

${ }^{a}$ University of São Paulo, Center for Nuclear Energy in Agriculture, 13416-000,

${ }^{\text {b} D e p a r t m e n t ~ o f ~ H y d r o b i o l o g y, ~ F e d e r a l ~ U n i v e r s i t y ~ o f ~ S a ̃ o ~ C a r l o s ~(U F S C a r), ~ 13565-905, ~}$

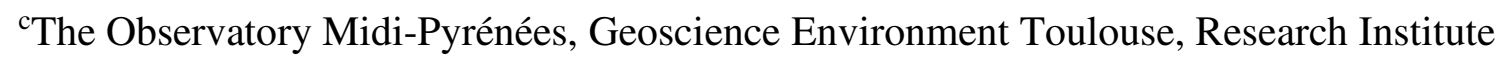
for Development, The National Center for Research Scientific, Paul Sabatier University,

${ }^{\mathrm{d}}$ Federal University of Mato Grosso do Sul, Faculty of Engineering, Architecture and Urbanism and Geography, 79070-900, Campo Grande, Mato Grosso do Sul, Brazil 


\section{Abstract}

28 Soda lakes environment is known to be variable and can have distinct differences according to geographical location. In this study, we investigated the effect of different environmental conditions of six adjacent soda lakes on bacterial communities and their functioning using a metagenomic approach combined with flow cytometry and chemical analyses. Ordination analysis using flow cytometry and water chemistry data from two sampling periods (wet and dry) clustered soda lakes in three different profiles: eutrophic turbid (ET), oligotrophic turbid (OT), and clear vegetated oligotrophic (CVO). Analysis of bacterial community composition and functioning corroborated this ordination; the exception was one ET lake, that was similar to one OT lake during the wet season, indicating drastic shifts between seasons. Microbial abundance and diversity increased during the dry period, along with a considerable number of limnological variables, all indicative of a strong effect of the precipitation-evaporation balance in these systems. Cyanobacteria were linked to high electric conductivity, $\mathrm{pH}$, and nutrient availability, whereas Actinobacteria, Alphaproteobacteria, and Betaproteobacteria were correlated with landscape morphology variability (surface water, surface perimeter, and lake volume) and less stressed lake conditions. Stress response metabolism was overrepresented in ET and OT lakes and underrepresented in CVO lakes. Altogether, this study illustrated the sensitivity of tropical soda lakes to climate change, as slight changes in hydrological regimes might produce drastic shifts in community diversity.

Keywords: Microbial ecology, extreme environment, saline-alkaline lakes, cyanobacterial blooms

\section{Introduction}

Extreme or hostile environments are characterized by severe physicochemical conditions that reduce the growth of organisms [1]. Despite these harsh conditions, such 
habitats can provide a diverse ecological niche for a wide range of microorganisms [2].

54 For example, sediments of hypersaline soda lakes host bacteria affiliated with candidate phyla radiation, an important and little explored group of fermentative microorganisms with a possible role in primary carbon degradation $[2,3]$. In addition, this role of aforementioned phyla highlights the importance of microbial activity in biogeochemical cycles in environments where other life forms are limited. The higher productivity observed in hypersaline soda lakes is sustained by microbial activity. Specifically, the cyanobacterial group acts as key species in biogeochemistry and ecosystem functioning due to primary productivity $[4,5]$.

Soda lakes are natural environments with rich carbonate and bicarbonate waters, comprising saline and hypersaline alkaline waters with elevated $\mathrm{pH}$ (ranging from 9.511) and salinities approaching saturation $[4,6]$. Several studies had attempted to unravel and map microbial communities inhabiting some soda lakes complexes as the East African Rift Valley, Carpathian Basin, Kulunda Steppe, and Cariboo Plateau [4,7,8]. The prokaryotic community identified in these lakes comprises Actinobacteria, Bacteroidetes, Cyanobacteria, Firmicutes, Proteobacteria, and some archaeal groups as Euryarchaeota $[5,7,9,10]$.

The Brazilian Pantanal biome (specifically in the Nhecolândia sub-region) hosts hundreds of pristine soda lakes (ca. 500-600) concentrated in a 27,000 km² area, and its microbial community remains underexplored [11]. Nuanced interactions between abiotic parameters, such as seasonal and spatial variations and resident microbial composition, may manifest in distinct Pantanal soda lake patterns [10,11]. The seasonality of Nhecolândia soda lakes is characterized by heavy rainfall during summer, followed by a strong evaporation process in the rest of the year, directly affecting the water level 
78 Nhecolândia soda lakes, integrating limnological, chemical, and microbiological data; (2)

79 to evaluate the environmental variables that drive microbial communities in Nhecolândia

80 soda lakes, and (3) to evaluate how seasonal variability in the hydrological balance

81 affected water chemistry and biotic compartments. To accomplish these goals, we

82 analyzed microbial communities from six lakes in contrasting periods of the hydrological

83 cycle using a combination of metagenomics and flow cytometry, concomitantly with

84 limnological variables and water chemistry.

85

86

\section{Methods}

87

88

89

90

91

92

93

\subsection{Sample site and Collection}

The lakes studied here are located in the São Roque Reserve in the Nhecolândia subregion, Mato Grosso do Sul State, Brazil. These soda lakes have relatively closed drainage without direct connection to major fluvial systems and are described as small (500 to 1000 m diameter), shallow (0.5 to $1.5 \mathrm{~m}$ deep), and round or irregular-shaped lakes $[10,11]$. The region is classified as a tropical savanna climate with a dry-winter period ("Aw" type) based on the Köppen classification, with an average air temperature ranging between $21^{\circ} \mathrm{C}$ and $32^{\circ} \mathrm{C}$ during the dry to wet period [13]. The annual precipitation in southwest Nhecolândia varies from 710 to $1200 \mathrm{~mm}$ in the south-southwest $[14,15]$.

Surface waters were collected from six lakes (Fig. 1), with four replicates separated by at least $100 \mathrm{~m}$. Sampling was carried out under both wet and dry conditions (Sep-2018 and Sep-2019, respectively) (Figure S1). Although a previous long-term survey has reported that rains are concentrated from October to March [12], the intra-annual rainfall variability can be pronounced, as was observed in both of the sampling years (Fig. S1). 
103 Monthly accumulated rainfall and land surface temperature (LST) data were obtained 104 from the Climate Hazards Group Infrared Precipitation [16] and MODIS LST datasets 105 respectively, using the Google Earth Engine platform. The water surface area $\left(\mathrm{km}^{2}\right)$ and 106 water perimeter $(\mathrm{km})$ were measured using PlanetScope imagery. The lake water volume $107\left(\mathrm{~m}^{3}\right)$ was obtained by multiplying the water surface area $\left(\mathrm{m}^{2}\right)$ with the average water depth 108 (m) of each lake.

109 Lake depth and water transparency were measured using a Secchi disc. The water 110 temperature, electrical conductivity (EC), $\mathrm{pH}$, and dissolved oxygen (DO) were measured 111 in situ using multiparameter probes (YSI-6600 V2 -Yellowspring, OH, USA and Horiba

112 U50, Kyoto, Japan) and interference by turbulence and bubbles were avoided. Water (10

113 L) was collected in a sterile container and stored in a $500 \mathrm{~mL}$ polyethylene bottle at $4^{\circ} \mathrm{C}$ 114 until further analysis.

\subsection{Flow cytometry and pigment analyses}

117 To determine heterotrophic prokaryote (HP) abundance, $1.2 \mathrm{~mL}$ water samples were 118 fixed in $1 \%$ formaldehyde, immediately flash-frozen in liquid nitrogen, and stored at $11980^{\circ} \mathrm{C}$ until analysis. Phototrophic picoplankton (PPP) cells were detected by 120 autofluorescence using a flow cytometer (see details in Supplementary Text S1).

121 Cytometrically defined populations among phototrophic picoplankton were classified 122 into five groups: phycocyanin-rich picocyanobacteria (PcyPC), phycoerythrin-rich 123 picocyanobacteria type I and II (PcyPE_1 and PcyPE_2), picoeukaryotes (Peuk), 124 nanoeukaryotes (Neuk), and phycoerythrin-rich eukaryotes or Cyanobacteria (Perec) $125[17,18]$. Chlorophyll- $a(\mathrm{Chl}-a)$ was extracted using $90 \%$ acetone and determined by 126 spectrophotometry using the EPA 446.0 method [19]. 
128 2.4. Microscopic identification of bloom-forming cyanobacteria

129 Water samples were observed under an optical microscope (Axioskop 40, Carl Zeiss,

130 Jena Germany) to identify the dominant bloom-forming cyanobacteria in each lake.

131 Morphological identification was performed based on the method described by Komárek

132 and Anagnostidis [20].

\subsection{Metagenomic DNA extraction and sequencing}

Environmental total DNA was extracted from lyophilized water sample $(0.5 \mathrm{~g})$

136 obtained in triplicate from each lake using the PowerLyzer PowerSoil DNA isolation kit

137 (Qiagen, Hilden, Germany). The integrity of the extracted DNA was checked using 138 agarose gel electrophoresis (1\% w/v) and quantified with the Qubit 2.0 fluorometer

139 (Thermo Fisher Scientific, Waltham, MA, USA). A total of 36 DNA samples were

140 obtained for shotgun-sequencing (6 lakes $\times 3$ replicates $\times 2$ seasons). Libraries were

141 generated using the Nextera XT DNA Sample Preparation kit (Illumina, Inc., San Diego,

142 CA, USA), following the manufacturer's recommendations, and sequenced on the

143 Illumina HiSeq 2500 platform.

\subsection{Bioinformatic analyses}

146 The raw sequence adapters were removed using CutAdapt [21] and quality

147 controlled using FastQC 0.10.1 [22]. The merging of paired ends reads was performed

148 using PEAR software [23]. Sequences smaller than $50 \mathrm{pb}$ and Phred $<20$ were removed

149 using Seqyclean 1.3.12 [24].

150 Metagenome reads were submitted for taxonomic and functional annotation

151 (RefSeq and SEED subsystems database) via the MG-RAST bioinformatics pipeline [25]. 
152 Hierarchical taxonomic and functional abundance profiles were generated using Best Hit

153 Classification, with a minimum alignment length of $15 \mathrm{bp}$, minimum e-value cutoff of

$15410^{-5}$, and a minimum percentage identity cutoff of $60 \%$.

\subsection{Water chemistry analyses}

157 Water samples were divided into three sub-samples for chemical analysis: unfiltered,

158 filtered through a glass microfiber with a pore size of $0.7 \mu \mathrm{m}$ (Whatman GF/F, Sigma-

159 Aldrich, St. Louis, MO, USA) and filtered through a $0.45 \mu \mathrm{m}$ pore size ester-cellulose membrane (Merck Millipore, Billerica, MA, USA). Unfiltered sub-samples were used to determine total nitrogen (TN) and total phosphorus (TP) content using the persulfate

162 method for simultaneous determination, following the American Public Health

163 Association method 4500-P J [26]. Filtered GF/F sub-samples were used to analyze

164 dissolved organic and inorganic carbon (DOC and DIC, respectively) and total dissolved nitrogen (TDN) by combustion (Shimadzu model TOC-5000A analyzer). Sub-samples filtered through a $0.45 \mu \mathrm{m}$ ester-cellulose membrane were used to determine the

167 concentration of the following ions: $\mathrm{NH}_{4}^{+}, \mathrm{NO}_{3}^{-}, \mathrm{NO}_{2}{ }^{-}$, by flow injection analyses [27].

168 Orthophosphate $\left(\mathrm{oPO}_{4}^{3-}\right)$ concentrations were quantified using the ascorbic acid method 169 [28]. Alkalinity was analyzed with $0.1 \mathrm{~mol} \mathrm{~L}^{-1}$ hydrochloric acid solution titration. Total 170 dissolved solids were determined using the Environmental Protection Agency method 1711684 [29]. Water salinity was estimated from the total amount of inorganic dissolved

172 solids in water samples [30]. Concentrations of $\mathrm{Na}^{+}, \mathrm{K}^{+}, \mathrm{Mg}^{2+}, \mathrm{Ca}^{2+}, \mathrm{Cl}^{-}$, and $\mathrm{SO}_{4}{ }^{2-}$ were 173 analyzed by ICS-90 ion chromatography (Dionex, Sunnyvale, CA, USA). Trace elements 174 such as $\mathrm{Al}, \mathrm{B}, \mathrm{Cu}, \mathrm{Fe}, \mathrm{Mn}, \mathrm{Ni}, \mathrm{Si}$, and $\mathrm{Zn}$ were determined by inductively coupled plasma optical emission spectrometry (ICP/OES, JY ULTIMA 2000, Longjumeau, France). 


\subsection{Data analysis}

178 Analyses of variance were measured using Tukey or Kruskal-Wallis tests and applied 179 to test for significant differences among lakes using the Multicomp package [31]. All 180 statistical assumptions were considered and are detailed described in Supplementary Text

181 S2. Principal component analysis (PCA) was performed using FactoMineR, with 182 environmental variables set as explanatory variables and cytometric data as 183 supplementary variables. Further, principal coordinate analysis (PCoA) was conducted to 184 explore microbial profiles with metagenomic data (class taxonomy level) among lake 185 typology using the FactoExtra package [32]. Alpha diversity, Chao1 richness, and 186 Shannon diversity analyses were performed using MicrobiomeAnalyst [33], with the data 187 rarefied to the minimum library size and scaled using the total sums.

\section{Results}

\subsection{Lake typology}

The six soda lakes showed remarkable differences in their watercolor,

192 limnological and cytometric profiles. In general, evaluated lakes showed a saline-alkaline 193 condition, with a $\mathrm{pH}$ gradient varying between 8.62 to 10.05 and salinity from 0.41 to

$1941.72 \mathrm{~g} \mathrm{~L}^{-1}$ (Table 1). A high to moderate productivity was observed, as evidenced by high chl- $a$ (up to $4123 \mu \mathrm{g} \mathrm{L}^{-1}$ ), DOC (16 to $252 \mathrm{mg} \mathrm{L}^{-1}$ ), TN (2.22 to $90 \mathrm{mg} \mathrm{L}^{-1}$ ) and ortophosphate ( 0.02 to $\left.22.81 \mathrm{mg} \mathrm{L}^{-1}\right)$ concentrations. Dissolved organic nitrogen ( 0.50 to

$\left.19745 \mathrm{mg} \mathrm{L}^{-1}\right)$ was the major source of $\mathrm{N}$, followed by inorganic forms such as $\mathrm{NH}_{4}^{+}(0.0194$ 198 to $1.18 \mathrm{mg} \mathrm{L}^{-1}$ ) and $\mathrm{NO}_{3}^{-}$(up to $0.98 \mathrm{mg} \mathrm{L}^{-1}$ ).

199 Seasonality was evident at the water column level, which ranged from 88 to 109 $\mathrm{cm}$ in wet and 53 to $77 \mathrm{~cm}$ in dry periods (Table 1), promoting changes in water chemistry and cytometric abundance. These variables were plotted in a PCA ordination, and three 
202 distinct groups were observed (ANOSIM $\mathrm{R}^{2}=0.55, \mathrm{p}=0.001$; PERMANOVA $\mathrm{p}=0.01$ ): the 203 first group (eutrophic turbid - ET) was composed of lakes 04SR, 05SR, and 08SR, the 204 second group (oligotrophic turbid - OT) was composed of 01SR and 06SR, and the third 205 group (clear vegetated oligotrophic - CVO) was composed exclusively of lake 07SR (Fig. 206 2A).

\subsection{An overview of metagenomic data and the microbiological observation}

Metagenomic sequencing recovered a total of 10,507,992 and 23,850,354 sequences

210 after trimming and removal of low-quality sequences for the wet and dry periods, 211 respectively (Table S1). The average sequence size varied between 105 and $107 \mathrm{bp}$ for 212 wet and 102 and 103 bp for dry conditions, whereas the GC content ranged from $48 \%$ to $21355 \%$ in wet and $46 \%$ to $58 \%$ in dry periods.

214 The most representative bacterial taxa (above 3\%) were Actinobacteria (19.80\%), 215 Cyanobacteria (17.70\%), Betaproteobacteria (12.93\%), Alphaproteobacteria (7.98\%), 216 Gammaproteobacteria (5.37\%), Flavobacteria (4.07\%), and Planctomycetacia (3.54\%) 217 (Fig. 3A).

218 The PCoA from taxonomic data followed the clustering observed for limnologic and 219 cytometric data (ET, OT, and CVO groups) with a clear separation between the dry and wet periods (x-axis, 48.5\%) (Fig. 3B). However, an overlap between one lake ET (05SR)

221 and one lake OT (01SR) was observed. In the wet period, 05SR lake was more similar to 222 OT lakes than ET, while in the dry period, 01SR lake was more similar to ET lakes.

223 The main differentiating factor between ET from OT and CVO lakes was the 224 presence of bloom-forming cyanobacteria. Trichomes of Arthrospira platensis 225 (Oscillatoriales) and Anabaenopsis elenkinii. (Nostocales) (observed under an optical 
microscope) were predominated during the dry period. A few unicellular cyanobacterium Geminocystis sp. (Chroococcales) was also observed in samples from the ET lakes.

\subsection{Specificity of each lake's group}

\subsubsection{Eutrophic turbid lakes (ET)}

ET lakes presented a natural cyanobacterial bloom from A. elenkinii or A. platensis species, resulting in greenish-colored waters. These lakes had high $\mathrm{pH}, \mathrm{EC}$, salinity, and alkalinity as compared with other lakes. Moreover, all these parameters were higher in the dry season than in the wet period (Table 1 and Table S2). High concentrations of nitrogen (TN, TDN, and $\mathrm{NH}_{4}{ }^{+}$) and phosphorus lead to low TN:TP ratios. The nutrientrichest lake was 04SR, covering 17.49 to $90.43 \mathrm{mg} \mathrm{L}^{-1}$ for $\mathrm{TN}$ and from 3.35 to $22.81 \mathrm{mg}$ $\mathrm{L}^{-1}$ for TP.

Cyanobacterial blooms reduced light penetration associated with high PPP abundance,

DOC, DO, and Chl- $a$ concentrations (Table 1 and Table S4). Chl- $a$ and DOC concentrations were enhanced during the dry period. Field measurements detected oxic conditions in all lakes during the dry period, while lakes 05SR and 08SR had anoxic conditions during the wet period as a consequence of the absence or low presence of light.

The HP and PPP population abundance, bacterial diversity, and richness index values (Table S4) were significantly higher in ET than those in OT and CVO, with slight fluctuations in seasonality (Fig. S2). However, the 05SR and 08SR lakes showed a higher diversity index during the dry period, whereas 04SR showed a higher diversity during the wet period (Fig. S2). Lakes 04SR and 05SR had higher richness index values during the dry period, whereas that for 08SR lake was observed during the wet period (Fig. S2). 
(dry)], Flavobacteria [5.76\% (wet), 4.10\% (dry)], Alphaproteobacteria [4.79\% (wet),

$25211.77 \%$ (dry)], and Gammaproteobacteria [4.11\% (wet), 6.91\% (dry)] (Fig. 3A and Fig.

253 S3). The relative abundances of Alphaproteobacteria, Betaproteobacteria, and

254 Cyanobacteria were lower during the wet period than during the dry period. For the

255 Actinobacteria, Flavobacteria and Planctomycetacia this pattern was the opposite (Fig.

$2563 \mathrm{~A})$.

257 The identified prevalent functions were "Fatty Acids, Lipids and Isoprenoids," "Iron 258 acquisition and metabolism," "Regulation and Cell signaling," "Potassium metabolism," 259 "Miscellaneous," "Photosynthesis" and "Dormancy and sporulation" (Fig. 3C and Fig. 260 S4). The "Carbohydrates" and "Virulence Diseases and Defense" were predominant in 261 the wet period compared to the dry period (Fig. 3C). The ordination analysis clustered the 262 05SR lake together with the OT and CVO (07SR) lakes as well as 08SR in the wet period. 263 This clustering could occur as a result of the differential abundance of "Carbohydrates" 264 (higher in 04SR and 08SR_dry) and "Membrane transport" (enriched on 04SR and 265 08SR_dry) functions (Fig S4).

\subsubsection{Oligotrophic turbid lake (OT)}

268 OT lakes were characterized by turbid waters due to the high concentration of mineralassociated organic matter resulting in blackish-colored waters. The $\mathrm{pH}, \mathrm{EC}$, salinity, and alkalinity of these lakes were lower than those in the ET lakes (Table 1 and Table S2).

271 Reduced concentrations of DOC and TN were found during the dry period. The major N

272 source varied between the lakes, where 06SR was enriched in nitrate and 01SR was 273 enriched in ammonium. In contrast, high values of TP and low to moderate N:P ratios 274 showed that $\mathrm{P}$ was not a limiting nutrient in these lakes. High concentrations of $\mathrm{SO}_{4}{ }^{2-}, \mathrm{Cl}^{-}$ 275 , Al, Fe, Cu, Mn, and Si were detected especially under dry conditions (Table S3). 
PPP and HP abundances were reduced compared to ET lakes (Table S4 and Table S5), but they were affected by seasonality. The bacterial richness had an intermediate level when compared to ET and CVO lakes, and in contrast to ET lakes, this index was higher during the wet period (Fig. S2A). The exception was the 01SR lake, where the bacterial diversity was higher in the dry period than in the wet period (Fig. S2B).

281 The prevalent bacterial classes found in these lakes were similar to those observed in

282 ET lakes, but Actinobacteria [22.29\% (wet), 22.62\% (dry)], Betaproteobacteria [12.13\% 283 (wet), 15.45\% (dry)], and Planctomycetacia [5.71\% (wet), 2.44\% (dry)] had a higher 284 relative abundance when compared to ET lakes. The seasonality effect was noticeable in 285 the relative abundance of Cyanobacteria (lower in the wet period) (Fig. 3A and Fig. S4). 286 Although these lakes (01SR and 06SR) showed similarities in their limnological 287 parameters, they host a different bacterial communities composition. Lake 06SR was enriched in Actinobacteria and Proteobacteria (Betaproteobacteria class), while the 01SR lake was enriched in low-frequency organisms (“Others") (Fig. S3).

290 The prevalent potential bacterial functions were "Metabolism of Aromatic 291 Compounds," "Respiration," "Secondary Metabolism," and "Stress Response” (Fig. 3C).

292 The "Nitrogen Metabolism" function was enriched on wet period while the "Phages, 293 Prophages, Transposable Elements, Plasmids" function was enriched on dry period. 294 Seasonality affected the distribution of potential functional genes in 01SR lake. During 295 the dry period, the 01SR lake samples were clustered with 05SR_dry and 08SR_wet lakes, 296 whereas the 01SR_wet samples were clustered with 04SR (both dry and wet) and 297 08SR_dry samples (Fig. S4). 
The CVO lake had crystalline water owing to its low turbidity and high light

301 penetration. This lake demonstrated the lowest concentrations of ions, $\mathrm{pH}$, and $\mathrm{EC}$ than

302 the other two lake types (Table 1). As observed for the previous group of lakes, these

303 variables were slightly increased in dry conditions. In contrast, the salinity and alkalinity

304 were higher during the wet period. In addition, the higher TN:TP ratios indicated a low

305 availability of TN and TP, resulting in low microbial abundance. The peuk and PcyPE_2

306 organisms were more abundant, while this lake had the lowest bacterial diversity (Table

307 S4; Fig. S2A).

308 The bacterial composition of the CVO lake was remarkably different from that of the 309 previous lake types. A higher relative abundance of Actinobacteria [28.28\% (wet),

$31028.58 \%$ (dry)], Proteobacteria (Betaproteobacteria) [22.14\% (wet), 25.57\% (dry)], and

311 Planctomycetacia [7.85\% (wet), 6.54\% (dry)] were observed. The relative abundances of

312 Actinobacteria and Proteobacteria (Betaproteobacteria) were reduced during the wet

313 period, whereas Planctomycetacia was increased (Fig. 3A).

314 The prevalent functional genes found were "Protein Metabolism," "Nucleosides and

315 Nucleotides," "Amino Acids and Derivatives," "Clustering based subsystem,"

316 "Phosphorus metabolism," "RNA Metabolism" and "Respiration" (Fig. 3C and Fig. S4).

317 "Cell wall and Capsule" and "Sulfur Metabolism" functions were enriched on the wet

318 period (Fig. 3C). The CVO lake clustered with the 05SR wet sample (ET lake) (Fig. S4).

320 4. Discussion

321 This study, which used a detailed set of limnologic parameters, sheds light on the 322 typology of Brazilian tropical soda lakes. Statistical and ordination analyses of the 323 limnological dataset clustered the lakes into three categories: ET, OT, and CVO. Bacterial 324 community composition also validated the division of these categories. 
326 Anabaenopsis elenkinii or Arthrospira platensis and their positive correlation with TP,

327 TN, DOC, EC, and $\mathrm{pH}$ as observed on PCA plot and correlation matrix. These eutrophic 328 conditions favor cyanobacterial blooms and promote changes in the environmental and 329 ecological conditions, as previously observed in other aquatic ecosystems [34]. The two 330 planktonic cyanobacteria have been reported as common inhabitants of several

331 Nhecolândia soda lakes and are important primary producers in these extreme habitats

$332[35,36]$. Furthermore, both cyanobacterial genera are associated with the occurrence of 333 blooms in other soda lakes [4].

334 The main differentiation factor between CVO and OT lakes was the higher 335 abundance of eukaryotic and phycoerythrin-rich organisms (prevalent in CVO), in 336 addition to the metal concentration and particulate solids in suspension (prevalent in OT).

337 Compared to ET, the OT and CVO lakes had less stressful environmental conditions, with 338 some of them exhibiting aquatic plants and other organisms, such as amphibians, slugs, 339 snails, and insects (field observations). Both lakes were positively correlated with depth,

340 volume, and water surface area and water surface perimeter relationship. Furthermore,

341 OT lakes were correlated with high concentrations of some ions, such as $\mathrm{Zn}, \mathrm{Fe}, \mathrm{Ni}, \mathrm{NO}_{3}{ }^{-}$

$342, \mathrm{SO}_{4}{ }^{2-}$, and $\mathrm{Si}$, indicating a more mineralized environment. The input of nutrients such 343 as organic matter, nitrogen, phosphorus, calcium, and iron ions, among others, may occur 344 due to the infiltration of runoff into the lakes, which could be intensified during heavy 345 rainfall in the wet period. This edge effect has been described for lakes, including soda 346 lakes in Russia [37,38]. Lakes are intimately connected to their surrounding land, 347 showing significant correlations between physicochemical and geomorphological 348 variables (especially water volume and altitude) [39, 40]. Notably, the enrichment of 
eukaryote and phycoerythrin-rich organisms in the CVO lake could be directly correlated to the runoff, as observed in other studies $[41,42]$.

Although clustered lakes suggested a uniform chemical and biological composition, each of them was highly diverse and preserved its traits. These soda lakes have unique features compared to other soda lakes worldwide, especially due to their remarkable seasonality [11]. Changes in intra-annual rainfall and long periods of drought can alter the water volume in lakes, and in the Nhecolandia region, some lakes can be completely dry, as occurred in 2017, 2020, and 2021. Hydrology is a key driver of phytoplankton and heterotrophic bacterial communities in tropical freshwater lakes, as well as soda lakes [43,44]. Water dynamics impact nutrient concentration and its flux by modulating the diverse components of the system [45]. Seasonality is a determinant of

360 the structure of the inhabiting microorganisms of soda lakes. The dry period was characterized by a high concentration of nutrients, light intensity, and temperature. These factors favor the occurrence of cyanobacterial blooms $[46,47]$. The bloom of the cyanobacterium A. platensis occurred in 04SR and 08SR lakes, while A. elenkinii blooms were observed only in lake 05SR under dry conditions. A. platensis appears to tolerate high salinity and grows at high nitrogen and phosphorus availability (low N:P ratios) [48]. In contrast, A. elenkinii requires a lower salinity level and nutrient concentration to flourish $[10,49,50]$.

The top-level heterotrophic bacteria of the ET lakes were Actinobacteria,

369 Bacteriodetes, Proteobacteria (Betaproteobacteria, Gammaproteobacteria,

370 Alphaproteobacteria) and Planctomycetacia. These bacterial groups have already been 371 described in association with cyanobacterial blooms in other soda lakes $[4,8,51]$.

372 Cyanobacteria release labile DOC through exudation during the bloom, thus stimulating 373 the proliferation of heterotrophic bacteria [52]. Lakes 04SR and 08SR had a similar 
composition of heterotrophic bacterial community with a slight difference from 05SR, as evidenced by PCoA analysis. This difference could be a result of the complex interactions established between biotic (cyanobacteria and heterotrophic bacteria) and abiotic factors, which modulate how these bacteria adapt to stress conditions and overcome this adversity $[52,53]$.

OT and CVO lakes with absence of cyanobacterial blooms were colonized mainly by Actinobacteria, Proteobacteria (Betaproteobacteria) and Planctomycetacia. A higher abundance of these phyla when Cyanobacteria population is low has been already described under oligotrophic conditions [10,54]. During the dry period, Alphaproteobacteria and Gammaproteobacteria were the most abundant. Members of these two bacterial classes are commonly reported in soda lakes of various salinity levels, and with the potential to use sulfur compounds as a primary or secondary energy source $[4,5,7]$.

The Nhecolândia soda lakes have unique abiotic conditions encompassing eutrophic conditions, hyposaline to saline content, and a low water level, which has never already been described all together for other soda lakes region. ET lakes showed

390 enrichment of bacterial functions associated with iron acquisition, motility, chemotaxis, virulence, and membrane transport. Some bacterial species have the potential to metabolize iron and other metals that can be discharged during rainfall runoff $[55,56]$. Moreover, cyanobacteria benefit from as they require ten-fold more iron than that required by heterotrophic bacteria to drive many processes, such as photosynthesis and

395 nitrogen fixation $[57,58]$. OT and CVO lakes were supplied with a high relative 396 abundance of genes associated with the metabolism of nitrogen, phosphorus, protein, and 397 respiration, which may potentially compensate for their oligotrophic conditions. A study on Arctic microbial mats demonstrated that microorganisms could maintain a nutrient- 
399 rich environment by promoting recycling and scavenging processes, intensifying genes

400 related to light, nitrogen, and phosphorus-related process [59]. In extreme environments,

401 a well-adapted microbial community has special machinery to maintain important

402 biogeochemical processes, even under stress conditions [7,60,61]. Stress response

403 metabolism was overrepresented in the ET and OT lakes. The stress metabolism category

404 encompasses the responses of osmotic, oxidative, heat shock, and detoxification [62].

405 The division of the lakes in the three typologies agreed with the variation in 406 bacterial composition. However, some lakes (01SR and 05SR) may shift their status from

407 ET to OT and vice versa, seasonally, depending on the hydrological balance. Changes in 408 water level promoted by the precipitation-evaporation balance alter nutrient availability 409 in the lakes, which favors cyanobacterial blooms in ET lakes and consequently modifies

410 the heterotrophic bacterial composition. The hydrological cycle has been relatively 411 unstable from year to year in the Nhecolândia subregion over the last decade. The dry or 412 wet periods may be intensified in a warming climate, resulting in short- and long-term 413 impacts on lake biogeochemistry and regional carbon budgets.

415 Supplementary Information

416 The online version contains supplementary material available at:

\section{Acknowledgements}

419 We thank the owner of the São Roque farm for permission to collect the water samples.

420 We want to thank Prof. J. A. Bendassolli for the ionic chromatography analyses. We also 421 thank the Center of Functional Genomics Applied to Agriculture and Agroenergy (USP, 422 Campus "Luiz de Queiroz") for generating the Illumina HiSeq data. 
424 MFF and TAP conceived the study. TAP, JSC, HS and ED collected the samples. TP, SC, 425 JSC, HS and ED analyzed the data. All authors were involved in writing the paper and 426 had final approval of the manuscript.

\section{Funding sources}

428 This research was supported by the São Paulo Research Foundation (FAPESP \#2016/14227-5). TAP is thankful to the FAPESP (\#2017/12644-0) for providing graduate

430 scholarship. MFF and HS received research fellowship (306803/2018-6 and 431 309514/2017-7, respectively) from the Brazilian National Council for Scientific and 432 Technological Development (CNPq).

\section{Competing interests}

434 The authors declare that the research was conducted in the absence of any commercial or 435 financial relationships that could be construed as a potential conflict of interest.

437 The sequence data (total of 36 metagenomes) have been deposited in the MG-RAST 438 database under the project named Pantanal and accession numbers: mgp88859 (2018) and 439 mgp92377 (2019).

\section{References} Viruses in extreme environments, current overview, and biotechnological potential. $444 \quad$ Viruses, 13(1), 81.

445 [2] Shu WS, Huang LN (2021) Microbial diversity in extreme environments. Nat Rev 446 Microbiol. https://doi.org/10.1038/s41579-021-00648-y. 

(2017) Members of the Candidate Phyla Radiation are functionally differentiated by carbon-and nitrogen-cycling capabilities. Microbiome, 5(1), 1-14. (2014) Microbial diversity and biogeochemical cycling in soda lakes. Extremophiles 18, 791-809. doi: 10.1007/s00792-014-0670-9. [5] Vavourakis CD, Andrei AS, Mehrshad M, Ghai R, Sorokin DY, Muyzer G (2018) A metagenomics roadmap to the uncultured genome diversity in hypersaline soda lake sediments. Microbiome, 6(1), 1-18.

[6] Tindall BJ (1988) Prokaryotic life in the alkaline, saline, athalassic environment. Halophilic bacteria 1:31-67. shared core microbiome in soda lakes separated by large distances. Nature communications, 10(1), 1-10.

[8] Felföldi T (2020) Microbial communities of soda lakes and pans in the Carpathian Basin: a review. Biologia Futura, 1-12. multiple extreme conditions. Extremophiles, 21(3), 639-649. L, Fiore MF (2018) Contrasting the Genetic Patterns of Microbial Communities in Soda Lakes with and without Cyanobacterial Bloom. Frontiers in Microbiology, 9, 244.

[11] Barbiero L, Neto MS, Braz RR, do Carmo JB, Rezende Filho AT, Mazzi E, Camargo PB (2018) Biogeochemical diversity, $\mathrm{O}_{2}$-supersaturation and hot moments of GHG emissions from shallow alkaline lakes in the Pantanal of Nhecolândia, Brazil. Science of the Total Environment, 619, 1420-1430. JI, Marques MI (2020) Quo vadis Pantanal? Expected precipitation extremes and drought dynamics from changing sea surface temperature. PLoS ONE 15(1): e0227437. ArcGis Desktop-ArcView. In: IBGE, editor. 

(2015) Geology and geomorphology of the Pantanal basin. In: Bergier, I., Assine,M.L. (Eds.), Dynamics of the Pantanal Wetland in South America. Springer International, Switzerland, pp. 23-50.

[16] Funk C, Peterson P, Landsfeld M, Pedreros, D Verdin, J Shukla, S Husak, G Rowland, J Harrison, L Hoell, A Michaelsen, J (2015) The climate hazards infrared precipitation with stations - a new environmental record for monitoring extremes. Scientific data, 2(1), 1-21.

[17] Sarmento H, Unrein F, Isumbisho M, Stenuite S, Gasol JM, Descy J-P (2008) Abundance and distribution of picoplankton in tropical, oligotrophic Lake Kivu, eastern Africa. Freshwater Biology, 53, 756-771. planktonic bacteria and understanding the structure of planktonic bacterial communities. Scientia Marina, 64(2), 197-224. [19] Arar EJ (1997) Method 446.0: In Vitro Determination of Chlorophylls a, b, c + c and Pheopigments in 1 2Marine And Freshwater Algae by Visible Spectrophotometry. U.S. Environmental Protection Agency, Washington, DC, EPA/600/R-15/005.

[20] Komarek J, Anagnostidis K (1989) Modern approach to the classification system of Cyanophytes 4-Nostocales. Archiv für Hydrobiologie. Supplementband. Monographische Beiträge, 82(3), 247-345.

[21] Martin M (2011) Cutadapt removes adapter sequences from high throughput sequencing reads. EMBnet Journal. 17:10-12.

[22] Andrews S (2010) FastQC: a quality control tool for high throughput sequence data.

[23] Zhang J, Kobert K, Flouri T, Stamatakis A (2014) PEAR: a fast and accurate Illumina Paired-End reAd mergeR. Bioinformatics, 30(5), 614-620.

511 Informatics (pp. 407-416).

512 [25] Meyer F, Paarman D, D'SouzaM, Olson R, Glass EM, Kubal M, EdwardsRA 513 (2008) The metagenomics RAST server-a public resource for the automatic 
phylogenetic and functional analysis of metagenomes. BMC bioinformatics, 9(1), 18.

[26] Federation WE, APH Association (2005) Standard methods for the examination of water and wastewater. American Public Health Association (APHA): Washington,

518 DC, USA.

[27] R̉užička J, Hansen EH (1975) Flow injection analyses: Part I. A new concept of fast continuous flow analysis. Analytica Chimica Acta, 78(1), 145-157. [28] Murphy J, Riley JP (1962) A modified single solution method for the determination of phosphate in natural waters. Analytica Chimica Acta, 27, 31-36. [29] Telliard WA (2001) Method 1684: Total, fixed, and volatile solids in water, solids, and biosolids. US Environmental Protection Agency, Washington. [30] Williams WD, Sherwood JE (1994) Definition and measurement of salinity in salt lakes. International Journal of Salt Lake Research, 3(1), 53-63. [31] Hothorn T, Bretz F, Westfall P, Heiberger RM, Schuetzenmeister A, Scheibe S, Hothorn MT, 2016 Package 'multcomp'. Simultaneous inference in general parametric models. Project for Statistical Computing, Vienna, Austria.

[32] Kassambara A, Mundt F, 2017 Package 'factoextra'. Extract and visualize the results of multivariate data analyses, 76 . MicrobiomeAnalyst: a web-based tool for comprehensive statistical, visual and metaanalysis of microbiome data. Nucleic acids research, 45(W1), W180-W188. Controlling harmful cyanobacterial blooms in a hyper-eutrophic lake (Lake Taihu, China): the need for a dual nutrient ( $\mathrm{N}$ and $\mathrm{P}$ ) management strategy. Water Research, 45(5), 1973-1983. forming cyanobacteria from Brazilian saline-alkaline lakes. Molecular Phylogenetics and Evolution, 109:105-112, 2017. 
[37] Sinyukovich VN, Latysheva IV., Makukhin VL (2020) Catastrophic floods on the southern tributaries of Lake Baikal and features of the atmospheric circulation. Limnology and Freshwater Biology, 564-565.

[38] Weng J, Zhuang K, Zhou J, Ding H (2020) A hybrid model for force prediction in orthogonal cutting with chamfered tools considering size and edge effect. The International Journal of Advanced Manufacturing Technology, 110(5), 1367-1384. [39] Coskun M, Musaoglu N (2004) Investigation of rainfall-runoff modelling of the Van Lake catchment by using remote sensing and GIS integration. In International Archives of Photogrammetry Remote Sensing Commission VII, XXth ISPRS Congress, Istanbul (pp. 12-23).

[40] Klimaszyk P, Brzeg A, Rzymski P, Piotrowicz R (2015) Black spots for aquatic and terrestrial ecosystems: impact of a perennial cormorant colony on the environment. Science of the Total Environment, 517, 222-231.

[41] Stefanidis K, Papastergiadou E (2012) Relationships between lake morphometry, water quality, and aquatic macrophytes, in greek lakes. Fresenius Environmental Bulletin, 21(10), 3018-3026. of a connected lake system. Frontiers in microbiology, 11, 89. [43] Ndebele-Murisa MR Musil, CF Raitt, L (2010) A review of phytoplankton dynamics in tropical African lakes. South African Journal of Science, 106(1), 13-18. [44] Freitas R, Vieira HH, de Moraes GP, de Melo ML, Vieira AAH, Sarmento H (2018) Productivity and rainfall drive bacterial metabolism in tropical cascading reservoirs. Hydrobiologia, 809(1), 233-246. saline lakes in the Brazilian Pantanal wetland: a polyphasic approach. Journal of Plankton Research, 38(6), 1389-1403. [46] Bakker ES, Hilt S (2016) Impact of water-level fluctuations on cyanobacterial blooms: options for management. Aquatic Ecology, 50(3), 485-498. 
[48] Kebede E (1997) Response of Spirulina platensis (= Arthrospira fusiformis) from Lake Chitu, Ethiopia, to salinity stress from sodium salts. Journal of Applied Phycology, 9(6), 551-558. S (2004) Cyanobacteria and cyanobacterial toxins in three alkaline Rift Valley lakes of Kenya-Lakes Bogoria, Nakuru and Elmenteita. Journal of Plankton Research, 26(8), 925-935.

[50] Krienitz L, Dadheech PK, Kotut K (2013) Mass developments of the cyanobacteria Anabaenopsis and Cyanospira (Nostocales) in the soda lakes of Kenya: ecological and systematic implications. Hydrobiologia, 703(1), 79-93. cyanobacteria and heterotrophic bacteria in cyanobacterial blooms in Lake Joutikas, Finland. Aquatic microbial ecology, 36(3), 201-211.

[52] Alvarenga DO, Andreote APD, Branco LHZ, Fiore MF (2017) Kryptousia macronema gen. nov., sp. nov. and Kryptousia microlepis sp. nov., nostocalean cyanobacteria isolated from phyllospheres. International journal of systematic and evolutionary microbiology, 67(9), 3301-3309.

[53] Nelson C, Garcia-Pichel F (2021) Beneficial cyanosphere heterotrophs accelerate establishment of cyanobacterial biocrust. Applied and environmental microbiology, 87(20), e01236-21.

[54] Ji B, Qin H, Guo S, Chen W, Zhang X, Liang J (2018) Bacterial communities of four adjacent fresh lakes at different trophic status. Ecotoxicology and environmental safety, 157, 388-394. Zavarzin GA (2006) Geoalkalibacter ferrihydriticusgen. nov. sp. nov., the first alkaliphilic representative of the family Geobacteraceae isolated from a soda lake. Microbiology 75:673-682. [56] Oremland RS, Saltikov CW, Stolz JF, Hollibaugh JT (2017) Autotrophic microbial arsenotrophy in arsenic-rich soda lakes. FEMS microbiology letters, 364(15). [57] Molot LA, Watson SB, Creed IF, Trick CG, McCabe SK, Verschoor MJ, Schiff SL (2014) A novel model for cyanobacteria bloom formation: the critical role of anoxia and ferrous iron. Freshwater Biology, 59(6), 1323-1340. cyanobacteria-from molecules to communities. Trends in Microbiology. 
612 [59] Varin T, Lovejoy C, Jungblut AD, Vincent WF, Corbeil J (2010) Metagenomic

613 profiling of Arctic microbial mat communities as nutrient scavenging and recycling 614 systems. Limnology and Oceanography, 55(5), 1901-1911.

615 [60] Jeffries TC, Seymour JR, Newton K, Smith RJ, Seuront L, Mitchell JG (2012)

616 Increases in the abundance of microbial genes encoding halotolerance and

617 photosynthesis along a sediment salinity gradient. Biogeosciences, 9(2), 815-825.

618 [61] Lay CY, Mykytczuk NC, Yergeau Ï., Lamarche-Gagnon G, Greer CW, Whyte

619 LG (2013) Defining the functional potential and active community members of a

620 sediment microbial community in a high-arctic hypersaline subzero spring. Applied 621 and environmental microbiology, 79(12), 3637-3648.

622 [62] Mangrola AV, Dudhagara P, Koringa P, Joshi CG, Patel RK (2015) Shotgun

623 metagenomic sequencing based microbial diversity assessment of Lasundra hot

624 spring, India. Genomics data, 4, 73-75.

625

626

627 


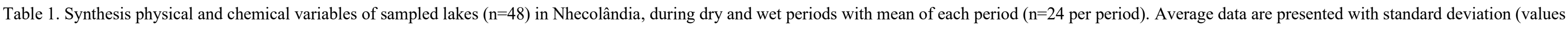
after \pm ).

\begin{tabular}{|c|c|c|c|c|c|c|c|}
\hline Variables & units & ET_w & ET_d & OT_w & OT_d & CVO_w & CVO_d \\
\hline Depth & $\mathrm{cm}$ & $94.83 \pm 19.94$ & $52.92 \pm 5.42$ & $88.37 \pm 9.61$ & $61.25 \pm 3.53$ & $109.5 \pm 7.37$ & $77.5 \pm 50$ \\
\hline WSA & $\mathrm{Km}^{2}$ & $0.22 \pm 0.12$ & $0.17 \pm 0.11$ & $0.19 \pm 0.09$ & $0.17 \pm 0.08$ & $0.19 \pm 0.00$ & $0.19 \pm 0.00$ \\
\hline WSP & $\mathrm{Km}$ & $2.15 \pm 1.10$ & $2.03 \pm 1.14$ & $1.69 \pm 0.54$ & $1.59 \pm 0.51$ & $1.72 \pm 0.00$ & $1.69 \pm 0.00$ \\
\hline WT & ${ }^{\circ} \mathrm{C}$ & $25.84 \pm 0.76$ & $29.92 \pm 4.05$ & $25.93 \pm 0.52$ & $29.30 \pm 4.24$ & $27.10 \pm 0.25$ & $27.41 \pm 0.15$ \\
\hline Secchi & $(\mathrm{cm})$ & $5 \pm 0.00$ & $7 \pm 3.72$ & $15.37 \pm 9.26$ & $6.75 \pm 3.28$ & $109.50 \pm 7.37$ & $77.50 \pm 5.00$ \\
\hline $\mathrm{pH}$ & & $9.75 \pm 0.27$ & $10.05 \pm 0.16$ & $9.18 \pm 0.11$ & $9.56 \pm 0.12$ & $8.62 \pm 0.05$ & $9.05 \pm 0.01$ \\
\hline DO & $\mathrm{mg} \mathrm{L}^{-1}$ & $11.71 \pm 3.67$ & $26.70 \pm 19.87$ & $5.99 \pm 0.58$ & $12.18 \pm 4.44$ & $6.60 \pm 0.58$ & $10.32 \pm 1.31$ \\
\hline $\mathrm{EC}$ & $\mathrm{mS} \mathrm{cm}^{-1}$ & $1.24 \pm 0.35$ & $2.70 \pm 0.39$ & $0.90 \pm 0.24$ & $1.64 \pm 0.39$ & $0.56 \pm 0.00$ & $0.69 \pm 0.00$ \\
\hline DOC & & $51.37 \pm 1.08$ & $164.50 \pm 67.58$ & $21.65 \pm 10.25$ & $55.18 \pm 21.98$ & $15.95 \pm 1.12$ & $33.96 \pm 14.72$ \\
\hline $\mathrm{TN}$ & $\mathrm{mg} \mathrm{L}^{-1}$ & $9.51 \pm 6.22$ & $56.01 \pm 28.76$ & $4.00 \pm 2.31$ & $21.81 \pm 7.85$ & $2.23 \pm 0.08$ & $3.54 \pm 0.34$ \\
\hline $\mathrm{TP}$ & & $1.41 \pm 1.45$ & $10.65 \pm 9.16$ & $0.72 \pm 0.63$ & $7.75 \pm 7.82$ & $0.06 \pm 0.04$ & $0.02 \pm 0.01$ \\
\hline TN:TP ratio & & $14.01 \pm 15.13$ & $7.40 \pm 3.91$ & $22.74 \pm 27.44$ & $27.70 \pm 31.74$ & $41.34 \pm 16.85$ & $146.11 \pm 28.00$ \\
\hline Chl-a & $\mu \mathrm{g} \mathrm{L}^{-1}$ & $61.90 \pm 44.86$ & $1814.12 \pm 1724.20$ & $18.80 \pm 9.60$ & $67.86 \pm 48.15$ & $5.90 \pm 0.93$ & $60.87 \pm 3.30$ \\
\hline PPP & cell $\mathrm{mL}^{-1}$ & $1.59 \times 10^{6} \pm 1.82 \times 10^{6}$ & $5.51 \times 10^{7} \pm 1.12 \times 10^{8}$ & $1.67 \times 10^{5} \pm 1.86 \times 10^{5}$ & $3.23 \times 10^{6} \pm 3.02 \times 10^{6}$ & $1.03 \times 10^{4} \pm 7.69 \times 10^{2}$ & $2.70 \times 10^{4} \pm 1.88 \times 10^{3}$ \\
\hline HP & & $3.44 \times 10^{7} \pm 4.42 \times 10^{7}$ & $2.00 \times 10^{8} \pm 2.30 \times 10^{8}$ & $1.01 \times 10^{7} \pm 1.08 \times 10^{7}$ & $8.41 \times 10^{6} \pm 8.83 \times 10^{6}$ & $2.33 \times 10^{6} \pm 6.76 \times 10^{4}$ & $5.18 \times 10^{5} \pm 1.39 \times 10^{5}$ \\
\hline
\end{tabular}

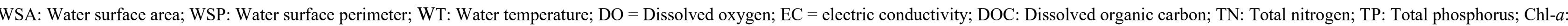
Chlorophyll- $a$; PPP: Photoautothrophic Picoplankton; HP: Heterotrophic Prokaryotes; N.A.: Not available data. 


\section{$648 \quad$ Figure legends}

649 Figure 1. Geographic distribution of Pantanal in South America (A); Localization of

650 Nhecolândia sub-region in Pantanal (B); Lakes complex distribution in Nhecolandia sub-

651 region with studied area highlighted (C); Satellite image of sampled lakes in studied area

652 (D); Aerial photography of sampled lakes:01SR (I); 04SR (II); 05SR (III); 06SR (IV); 653 07SR (V); 08SR (VI).

654 Figure 2. Principal component analysis (PCA) of individuals considering the lake types 655 (A). PCA of variables with supplementary information such as of chlorophyll-a (Chl-a), 656 cytometric population abundances (B). Phycocyanin-rich picocyanobacteria (PcyPC), 657 phycoerythrin-rich picocyanobacteria type I and II (PcyPE_1 and PcyPE_2), 658 picoeukaryotes (Peuk), nanoeukaryotes (Neuk) and phycoerythrin rich eukaryotes or 659 cyanobacteria (Perec). Illustrative scheme for each lake type and physical-chemical 660 patterns (C).

661 Figure 3. Bar plot of microbial community relative abundance of each lake type and 662 seasonal condition at class level (A). Principal Coordinate Analysis of community 663 structure considering "class level" of each lake type (B). Heatmap of functional genes 664 (SEED subsystem database level 1) of each lake type. 
666 Figure 1.

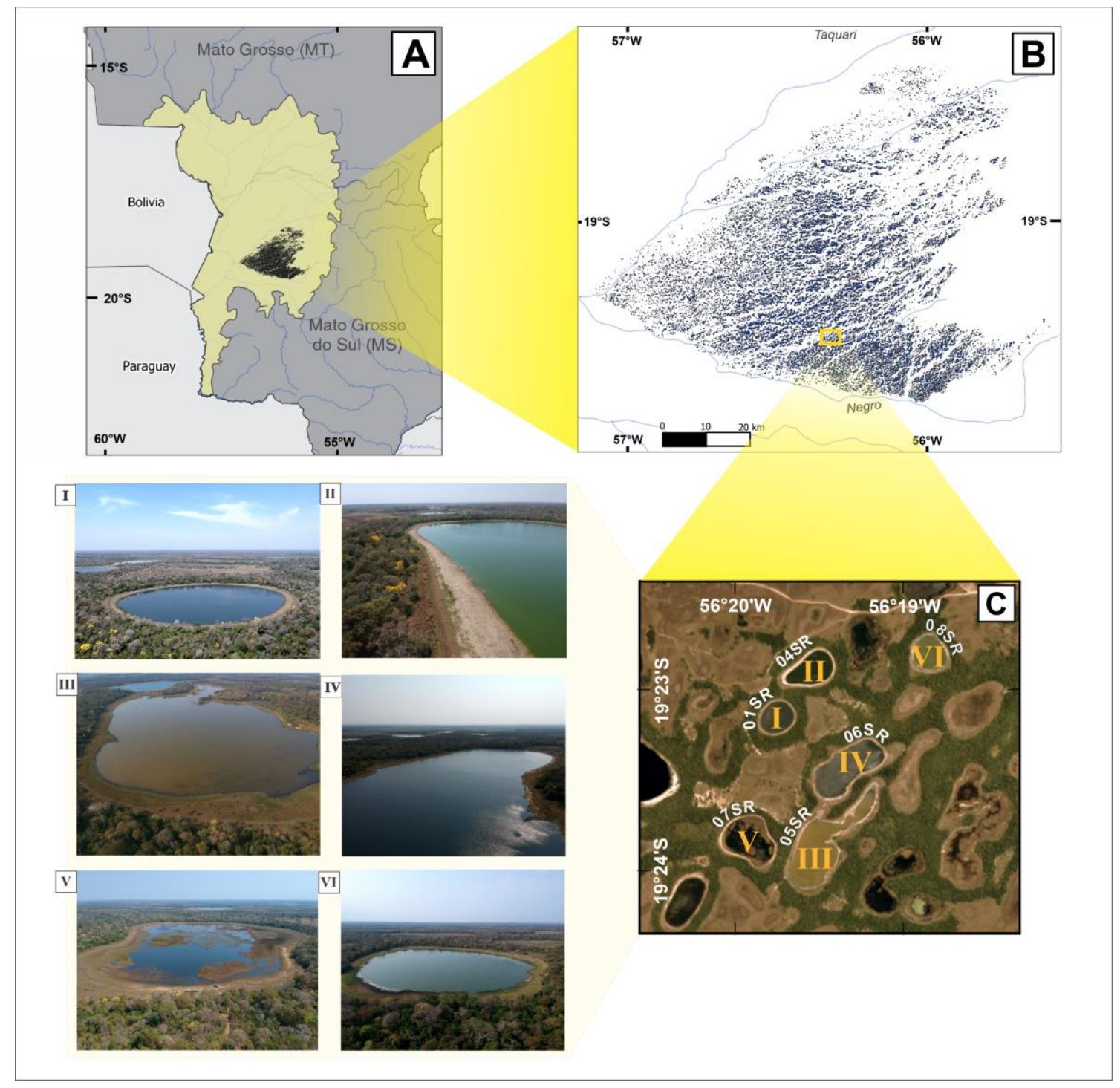

668

669 
Figure 2.

A)
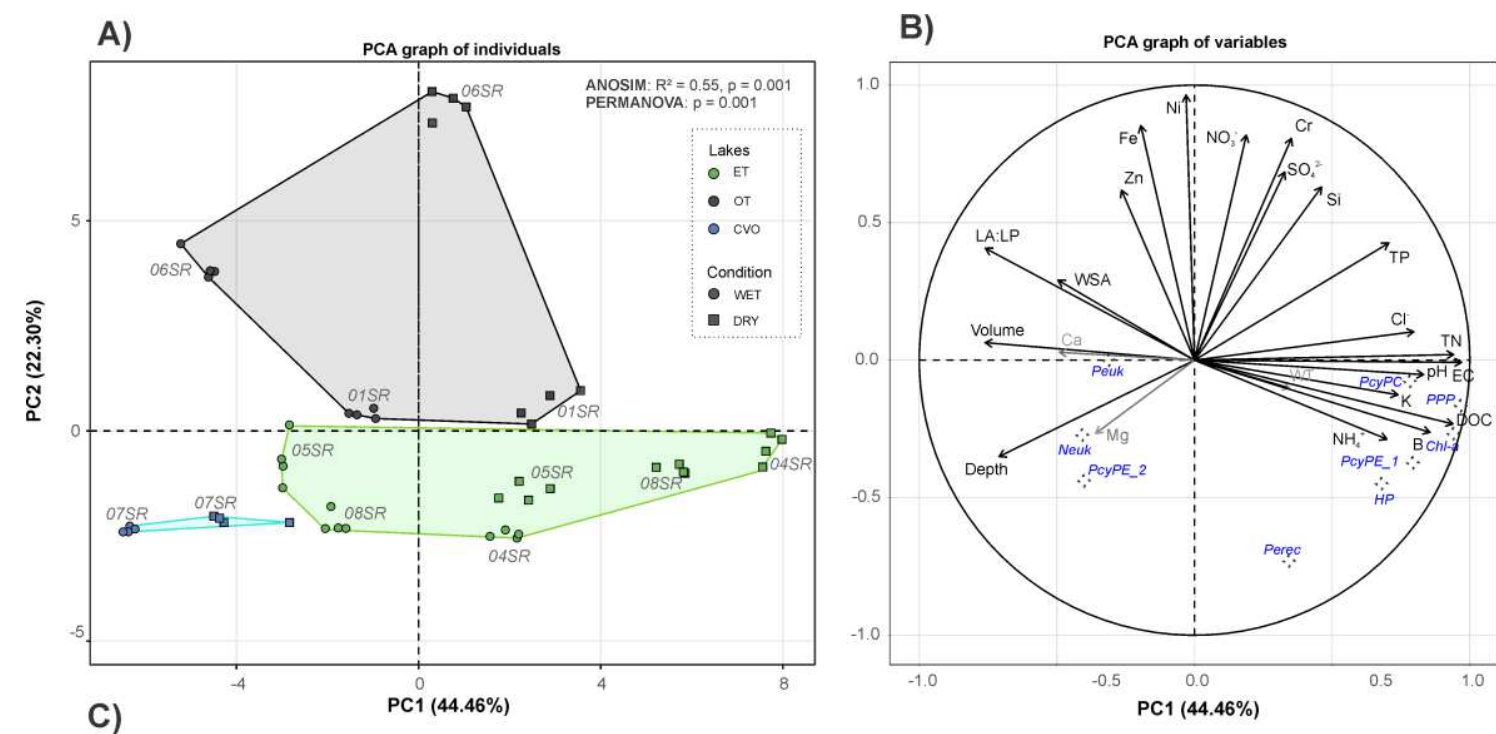

C

\begin{tabular}{|l|l|l|l|}
\hline EUTROPHIC TURBID LAKES (ET) & CLEAR VEGETATED OLIGOTROPHIC LAKE (CVO) \\
\hline $\begin{array}{l}\text { Salinity } \\
\text { Alkalinity } \\
\text { Micrient availability }\end{array}$ & $\begin{array}{l}\text { Salinity } \\
\text { Alkalinity } \\
\text { Nutrient availability } \\
\text { Microbial Abundance }\end{array}$ & $\begin{array}{l}\text { Salinity } \\
\text { Alkalinity } \\
\text { Nutrient availability } \\
\text { Microbial Abundance }\end{array}$ \\
\hline
\end{tabular}


673 Figure 3.
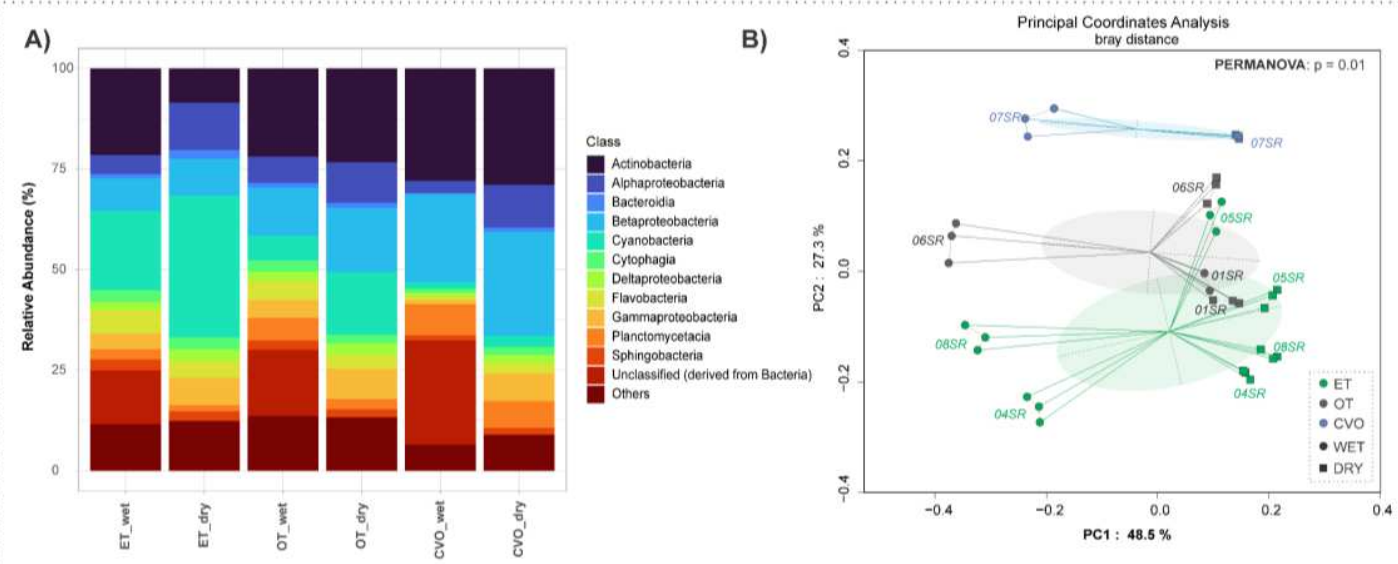

C)

674

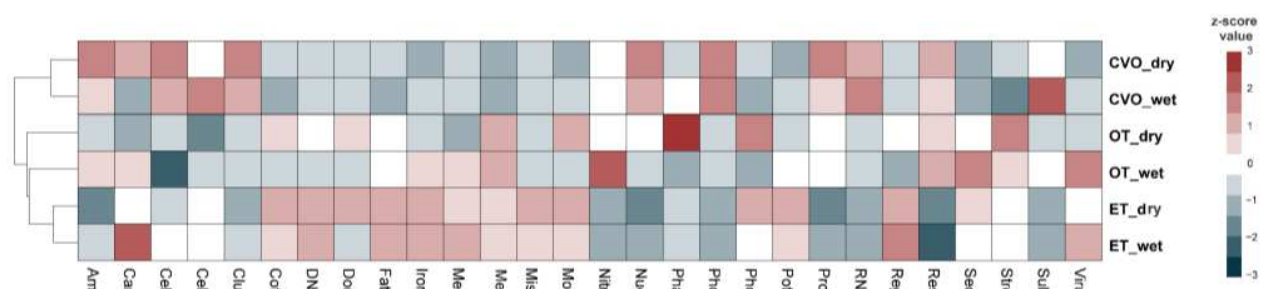

675

676 


\section{Supplementary Files}

This is a list of supplementary files associated with this preprint. Click to download.

- SupplementaryMaterials.pdf 